\title{
EARLY CHILDHOOD EDUCATION
}

\author{
UDC 371.011 (07)a \\ DOI 10.35433/pedagogy.1(96).2019.5-10
}

O. O. Maksymova,
PhD in Pedagogical Sciences, Associate Professor
(Zhytomyr Ivan Franko State University)
helen . maks23@ukr . net
ORCID: $0000-0003-1590-4339$

\section{DIAGNOSIS OF THE INTERPERSONAL TOLERANCE MANIFESTATION OF SENIOR PRESCHOOL CHILDREN}

The article analyses the research methodology of levels of interpersonal tolerance manifestation among senior preschool children according to proposed criteria. Based on the structure of the tolerant personality of the senior preschool child, which consists of cognitive, emotional, motivational, evaluative, and behavioral components, the following criteria for diagnosing interpersonal tolerance of children has been singled out. These consist of the completeness of knowledge about society and about oneself, positive emotional intentions, social motives, acceptance of a human being as the supreme value, impartial assessment of actions and personality traits, tolerant behavior, and social competence. Each criterion is measured by the indicators presented in the article. Based on the existing academic literature, the following methods and techniques for diagnosing the peculiarities and levels of interpersonal tolerance formation of six year old children are analysed: conversation, observation, K. Taylor's game test "Tale", the projective technique "Cactus", icons, drawing, the methodology "Diagnosis of socio-psychological settings of the personality in the motivational sphere" by O. F. Potemkin, the test "Drabinka", and the express diagnostics of values by T. Pirozhenko, S. Ladyvir.

The experimental work carried out made it possible to draw conclusions about the major problems and shortcomings that take place in the structure of the tolerant personality of the senior preschool child. Furthermore, these conclusions point towards the direction of further work that is needed to increase the level of interpersonal tolerance formation. In particular, this applies to the knowledge of peoples and nations living in other countries, including their peculiarities and traditions. Additional work is also required in the sensory

sphere, the ability to respond to the condition of another person, and detachment from one's own selfish position. Therefore, it will be appropriate to focus on the development of the child's decentralization and selfassessment. The obtained results lend support to simulating the content-technological support that will increase the level of interpersonal tolerance of children.

Key words: interpersonal tolerance, diagnostic criteria, indicators of manifestation, methods, diagnostic methods.

Introduction. Moral education is an acute problem in our society. In the post-Soviet era, much attention has been focused on material well-being, and, unfortunately, the spiritual side of education is suffering. Values have shifted, and the importance of universal human ideals was gradually replaced by the present-day focus on material ones. Contemporarily, we note a lack of understanding and sympathy among young people, including an absence of the desire to help. Instead, people understand and accept only their own point of view. Therefore, in order to preserve peace and harmony among peoples, it is necessary to increase the focus on ethical education and, in particular, on tolerance as one of its components.

The analysis of research articles and publications on the topic. Different aspects of this problem have been studied by scientists. In particular, the topic's historical perspective has been investigated by I. Vishensky, F.-M. Volter, K.-A. Helvetius, V. Lipinsky, J. Lock, J. Mill, S.-L. de Montesquieu, and T. Mor. Taking into account the values present, tolerance was studied by A. Asmolov, I. Bekh, E. Golovakh, E. Zielenov, I. Zyazyun, G. Soldatov, and L. Khoruzha. Methodological aspects of tolerance upbringing were revealed by I. Brodov, A. Golenkov, N. Stasiuk, O. Shcherbak. Presently, only a few studies have been conducted on the topic of tolerance formation among preschool children (T. Ponimanska, T. Pirozhenko, S. Ladyvir, L. Solovyov). 
Despite the considerable scientific interest regarding how to successfully utilize education in the formation of a tolerant personality, the majority of research is still focused on schoolchildren. In the case of preschoolers, diagnosis of the tolerant - intolerant position of the child is still unclear.

The purpose of the article is to highlight methodical principles of diagnosing levels of interpersonal tolerance formation among senior preschool-aged children according to the identified criteria.

Results. Interpersonal tolerance can be defined as the ability to respect, understand, recognize and accept another person. This includes respecting another person's position on social, political, religious, etc. views, paying special attitude to the rich diversity of cultures in our world, forms of human expression and ways of individual manifestation. Cognitive, emotional, motivational, evaluative, and behavioral components are highlighted in the structure of the tolerant personality [3]. On the basis of the components selected, the following criteria and indicators of the levels of interpersonal tolerance formation among older preschoolers are identified (see Table 1).

Table 1

Criteria and Indicators of Levels of Interpersonal Tolerance Formation among Older Preschoolers

\begin{tabular}{|l|l|l|}
\hline \multicolumn{1}{|c|}{ Components } & \multicolumn{1}{|c|}{ Criteria } & \multicolumn{1}{|c|}{ Indicators } \\
\hline Cognitive & $\begin{array}{l}\text { Knowledge about the society } \\
\text { and oneself }\end{array}$ & $\begin{array}{l}\text { Knowledge about oneself, } \\
\text { moral norms, identification }\end{array}$ \\
\hline Motivational & $\begin{array}{l}\text { Positive emotional attitude, } \\
\text { social motives }\end{array}$ & $\begin{array}{l}\text { Orientation in feelings and } \\
\text { emotions, positive emotional } \\
\text { attitude, expression of } \\
\text { emotions, emotional liability, } \\
\text { joy of communication, } \\
\text { interest, empathy, altruism, } \\
\text { need for communication, } \\
\text { wish to help others }\end{array}$ \\
\hline Evaluative & $\begin{array}{l}\text { Acceptance of a human- } \\
\text { being as the highest value, } \\
\text { impartial evaluation of } \\
\text { actions and personality traits }\end{array}$ & $\begin{array}{l}\text { Valuable attitude towards } \\
\text { people, impartial evaluation } \\
\text { of oneself and others, } \\
\text { decentering, justice }\end{array}$ \\
\hline Behavioral & $\begin{array}{l}\text { Tolerant behavior, social } \\
\text { competence }\end{array}$ & $\begin{array}{l}\text { Ability to anden, } \\
\text { communicate and act without } \\
\text { conflicts, perform moral } \\
\text { actions willingly }\end{array}$ \\
\hline
\end{tabular}

In order to diagnose children's knowledge of themselves, people and society, individual interviews were organised. The children were asked the following questions: Who are you? What kind of person are you? What do you think is a family? What are the responsibilities of the father, mother, brother and / or sister? What are your responsibilites? What feelings do you have for your mom, dad, brother and / or sister? What are your family's traditions? How do you relax? What relatives do you have? What country do you live in? Who is a Ukrainian? Do you know people of other nationalities, who are from other countries? What are their names? How are you similar to them? How are you different from them? Would you like to have a chat or make friends with a child from another country?

To establish the orientation of children in the emotional sphere we used a specialized game test by K. Taylor called "Tale". Included within "Tale" is the game "I feel" which was adjusted for the needs of the study. The game was conducted individually. The child was first asked to 
draw a large circle. Within the circle, the child was asked to put icons that resemble feelings known to the child. The child formulated the feeling in their own words, but was helped when needed. This included trying to extend the range of the child's feelings with the help of direct questions (What did you feel when you took your favorite toy? What did you feel when your friend fell and hit his leg?).

Next, quarrels between children, or between children and adults, were added. These included the following: the desire to possess the same object, misunderstandings in the game, anger resulting from tattling, failure to fulfill a promise to parents, the child's image of the mother who refused to buy something, accusations of a younger brother and / or sister, etc. Circles were drawn according to the number of participants in the conflict, with the names in each. Real stories were often used, particularly stories that the children themselves described. Finally, the child spoke about his experiences associated with the participants in this conflict using the feelings he knew. Present within the experiment were both quantitative and qualitative analyses. Therefore, the main objective was not to fill all circles, but to listen to the child and to discuss his feelings and reasons for experiencing them. Furthermore, it was important to discuss what the feelings were connected to and what results they would have in the future.

The exercise "Feeling" was also carried out, the content of which aims to indicate the degree of a child's orientation in different feelings, including how these feelings arise, what these feelings are, what these feelings can tell us, and how diverse these feelings are. A preschooler was given the task of drawing a face that reflects a certain feeling. Variations in the drawings were different, but in the majority of cases it was either a schematic face (pictogram), or a picture of a girl or boy. Then the child was asked the following questions: "Why is this face joyful / evil / sad / terrified / frightened / surprised? What do you think about this person? Why? Draw a speech bubble and predict what this person would say."

As the emotional state of the preschool child affects his attitude towards adults and other children, informing his interactions with them, considerable attention has been devoted to the study of this indicator. The formation of a positive perception of the world, as well as of the people in it, is an important component that indicates the presence of positive emotions, which further determine the degree of tolerance to another person. Peculiarities of the child's emotional sphere were defined based on several indicators. Emotional background can be defined as an established emotional state, either positive or negative, that shows the degree of emotional well being of the child. Expressiveness of emotions helps to establish how rich and diverse the emotional world of the child is. This includes whether he can express emotions and whether those emotions are monotonous and inconspicuous, as well as whether the situation corresponds to the appearance of certain emotions. Lastly, emotional liability corresponds to the excessive mobility of emotions experienced by children, manifesting in quick and easy mood changes.

The main method for determining a child's emotional state was observation. The most common emotions experienced by children were joy (in situations of successful performance of the assignment, approval of an adult, meeting with a friend, during a game, etc.), surprise (appearance of someone or something unusual in an unusual situation), fear (when a toy breaks, quarrels, fights, prohibition), anger (when a close person did not respond to a request, an unjust punishment, when others take things that belong to a child), and sadness (when mother leaves him alone in the kindergarten).

When conducting observations, attention was paid to the ways in which the child established contact with other children, including whether he needed some help from adults or avoided contact with all together. The child's reaction to encouragement or condemnation was noted: adequate, positive, indifferent, negative or aggression. 
After observing the children in differing situations, conclusions were drawn concerning their overall emotional states, which were identified as stable, variable, normal, elevated or decreased, euphoric, depressive or contrasting. Additionally, the technique "Cactus" was also used to determine the emotional state of the children.

In order to diagnose the motivational sphere of the preschool child, the modified methodology "Diagnosis of socio-psychological settings of the person in a motivational area", developed by O.F. Potemkin, was used. A scale aimed at identifying the position of "altruism-egoism" was of great interest to the study. The children were interviewed and asked one questions at a time to which they had to answer either "yes" or "no". If the child experienced difficulty answering the question or did not understand the question, further life examples were provided to the child in hopes of clarify the meaning of the question.

The test called "Drabinka" helped to diagnose self-esteem and the level of a child's decentralization. When assessing the child's answers, attention was drawn to the difficulties that were encountered, the reluctance to answer questions about certain individuals and the uncertainty in the responses.

The value sphere of the child was studied with the help of the express diagnosis compiled by T. Pirozhenko and S. Ladyvir, as well as on the basis of the methods for studying values by M. Rokich, M. Seligman, and K. Petersen. Scientists selected 17 basic value orientations that were further divided into two groups: values-benefits (values that correspond to the material and spiritual needs of the child) and values-regulations (values that cover moral, ethical, legal, aesthetic norms and ideals, traditions, customs). They displayed the following spheres of existence: "I", "Other people", "World of nature, technology, art". Values-benefits include happiness, family, money, health, friendship, the beauty of nature, the beauty of technology, the beauty of art, and creativity. Life and feelings of another person, autonomy, curiosity, purposefulness, courage, perseverance, and confidence belong to the group of values-regulations.

According to the contents of values, children were offered black and white pictures (ensuring that color had no emotional influence over the child) that depicted various values and were close to children's experience. First, the child's ability to characterize and explain values, as well as correlate them with the pictures, was checked. Generally, children selected the most important images, being allowed to select 8 picture-values. The sequence of selection was used to determine the content of the leading values of the senior preschool child.

Analyzing the children's responses in the first part of the experiment, the conclusion was reached that children oriented better with specific concepts rather than with abstract ones and that this is a natural response for their age. For example, knowledge, understanding, and explanation of such categories as the family (called family members, grandparents, grandfathers), money (thing you use to buy products, things, entertainment), and health (absence of pain) did not cause any difficulty for them. Furthermore, it was quite simple for them to analyze the concept of "happiness" which included having fun, getting what you want, being given a new toy, receiving praise, etc. It was much harder for them to interpret and derive meaning from relevant pictures of values-features of character (curiosity, confidence, purposefulness, persistence).

The main goal in the second part of the experiment was to rank values. It should be noted that a direct connection between the understanding of a certain value and its choice was observed. This means that children did not choose categories that they could not explain. Many children put family in the first place. It is believed that this is due to the age dependency on parents and their attachment to the family. Additionally, a significant number of children chose happiness. As the children associated happiness with their favorite activities (playing or painting), the attitude to themselves (when you are loved and praised), and getting 
what they want (when parents buy a new toy), the reason for this choice becomes clear. As the choice of the value "money" was among the four most popular, it can be stated that the children were aware of its significance in obtaining necessary or desired things (food, clothing, entertainment, toys, travel, etc.). The fourth most chosen value was health and the least number of choices were for "beauty of art" and "beauty of technology".

The manifestations of social competence and the frequency of cases of tolerant behavior were determined by the methods of programmable observation during games, the implementation of common tasks and various moments of life. In order to structure observation records, the method of "polar profiles" was used. The children's behavior and actions were assessed with the help of pairs of antonyms: conflict-free in communication and activities 3210123 gets into conflicts; is able to listen 3210123 does not hear the other child; provides assistance 3210123 shows indifference, accepts help 3210123 denies assistance, moral 3210123 immoral.

A separate record was kept for each child, and during the week of observation the features of her behavior with peers and elders were recorded. A survey of educators was also conducted, which took into account their assessment of pupils' behavioral manifestations regarding the investigated aspect.

Conclusions. Having conducted diagnostic work among senior preschool children, areas of work were identified that would increase the level of interpersonal tolerance formation. In particular, knowledge about society, as a rule, did not go beyond the child's own experience. It was also determined that it is difficult to assimilate information about different countries and peoples. This area requires additional work in the sensory field, especially focused on the ability to see and respond to the emotional states of another person. As the senior preschool period is a turning point in terms of leaving the egocentric position and learning to perceive the other as a self-sufficient personality, it is appropriate to give much attention to the development of a child's decentralization and self-assessment.

\section{REFERENCES (TRANSLATED \& TRANSLITERATED)}

1. Fedorova, M.A. (2016) Obgruntuvannia strukturnykh kharakterystyk moralnykh tsinnostei ditei starshoho doshkilnoho viku [Structural characteristics of senior preschoolers' moral values]. Nauka $i$ osvita - Science and Education, 9, 88-92 [in Ukrainian].

2. Ladyvir, S., Dolynna, O., Kotyrlo, V., Kulachkivska, S., Tyshchenko S. et al. (2010) Vykhovannia humannykh pochuttiv u ditei [Bringing up human feelings to children]. Ternopil: Mandrivets [in Ukrainian].

3. Maksymova, O.O. (2017) Zmistova struktura tolerantnosti ditei starshoho doshkilnoho viku [Content structure of tolerance of children of senior preschool age]. Naukovi zapysky Vinnytskoho derzhavnoho pedahohichnoho universytetu imeni Mykhaila Kotsiubynskoho - Scientific Papers of the Vinnytsia Mykhailo Kotsiubynsky State Pedagogical University, 52, 37-41.Vinnytsia: TOV "Nilan LTD" [in Ukrainian].

Received: December 20, 2018

Accepted: March 14, 2019

Діагностика прояву міжособистісної толерантності у стариих доикільників.

Стаття розкриває методику дослідження рівнів прояву міжособистісної толерантності старшими дошкільниками згідно запропонованих критеріїв. 3 опорою на структуру толерантної особистості старшого дошкільника, яка містить когнітивний, емоційно-мотиваційний, оцінно-ціннісний, поведінковий компоненти, виокремлено наступні критерї діагностики міжособистісної толерантності у дітей: повнота знань про суспільство, про себе; позитивна емоційна налаштованість; просоціальні мотиви; прийняття людини як найвищої цінності, об 'єктивна оцінка вчинків, якостей особистості; толерантна поведінка, соціальна компетентність. Кожен критерій вимірюється представленими у статті показниками. На підставі опрацьованої літератури пропонуються такі методи і методики, що дають можливість продіагностувати особливості та рівні вихованості міжособистісної 
толерантності у дітей 6-го року життя: бесіда, спостереження, ігровий тест К. Тейлора "Казка", проективна методика "Кактус", малювання піктограм, методика "Діагностика соціально-психологічних установок особистості в мотиваційно-потребній сфері", (О. Ф. Потьомкіна), тест "Драбинка". експрес діагностика иінностей за Т. Піроженко, С. Ладивір.

Проведена експериментальна робота дозволила зробити висновки про найбільші проблеми $i$ недоопрачювання, які мають місие в структурі толерантної особистості старшого дошкільника, $i$ вказала на напрями роботи, яким треба приділити більше уваги для підвищення рівня сформованості

міжособистісної толерантності у дітей. Зокрема, ие стосується знань про народи і нації, які проживають в інших країнах, їх особливості і традииії. Також потребує додаткової роботи почуттєва сфера, уміння реагувати на стан іншої людини, відмежовуючись від власної егоїстичної позиції. Тому доречною буде і посилення уваги на розвиток децентрації та самооиінки дитини. Отримані результати дають підстави змоделювати змістово-технологічне забезпечення, яке сприятиме підвищенню рівня міжособистісної толерантності дітей.

Ключові слова: міжособистісна толерантність, критерії діагностики, показники прояву, методи, методики діагностики. 